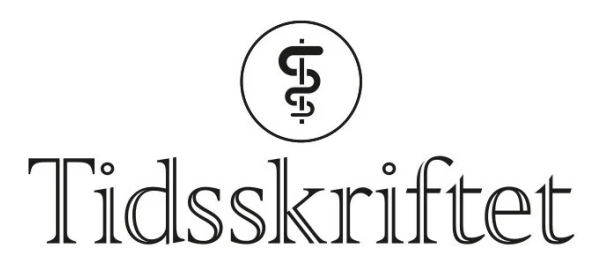

DEN NORSKE LEGEFORENING

\title{
Transferrinmetning ikke screeningtest alene
}

\author{
BREV TIL REDAKTØREN
}

TORE BJERKE

Høgskolen i Lillehammer

Arvelig hemokromatose har vært viet en del oppmerksomhet i det norske medisinske miljøet de siste årene, og internasjonalt er regulering av jernmetabolismen et omfattende forskningsfelt. Viktige artikler publisert i Tidsskriftet fører forhåpentligvis til at flere leger undersøker jernlager hos pasienter som kommer med såkalte uspesifikke symptomer. Det er imidlertid ett viktig forhold som bør presiseres klarere: Man kan ikke bruke bare transferrinmetning som kriterium for videre utredning av et eventuelt tilfelle av arvelig hemokromatose. Gjør man det, overses de tilfellene av hemokromatose der transferritmetning ikke er forhøyet, men der ferritinnivået likevel kan være svært høyt. Dette er ofte tilfellet for hemokromatose type $4(\underline{1}, \underline{2})$, også kalt «The ferroportin disease». Berit Borch-Iohnsen og medarbeidere skriver i Tidsskriftet nr. 9/2009 at tilstanden er sjelden (3). Dette er imidlertid slett ikke sikkert, siden flere epidemiologiske undersøkelser (for eksempel Helseundersøkelsen i Nord-Trøndelag) har basert sine estimater av utbredelse av hemokromatose på transferritinmetning som screeningtest (4). Hemokromatose type 4, som skyldes en eller flere mutasjoner på SLC40A1-genet på kromosom 2 (autosomalt dominant arv), kan forekomme langt oftere enn antatt, fordi man ofte går videre med gentest bare om transferritinnivået er forhøyet.

I en av Tidsskriftets tidligere artikler er ett hovedbudskap at «Når både serum-ferritin og transferrinmetning er forhøyet, bør det utføres gentest» (5). Dette bekrefter Tor-Arne Hagve og medarbeidere i Tidsskriftet nr. 9/2009, men de skriver også at i praksis gir høy transferrinmetning og/eller plasma-ferritin mistanke om hemokromatose (므). Ut fra den mengde publikasjoner som har kommet de siste årene om hemokromatose type 4, er det min overbevisning at denne tilstanden ikke er så sjelden, og at forhøyet ferritinnivå alene bør lede legen til videre undersøkelser. Gentesten bør da omfatte fokus på SLC4OA1-genet på kromosom 2, ikke bare de to bedre kjente mutasjonene på HFE-genet ( $\mathrm{C}_{282} \mathrm{Y}$ og $\left.\mathrm{H}_{3} \mathrm{D}\right)$.

\section{LITTERATUR}

1. Pietrangelo A. The ferroportin disease. Blood Cells Mol Dis 2004; 32:131-8. 
2. Cemonesi L, Forni GL, Soriani N et al. Genetic and clinical heterogeneity of ferroportin disease. $\mathrm{Br}$ J Haematol 2005; 131: 663-70.

3. Borch-Iohnsen B, Hagve T-A, Hauge A et al. Regulering av jernbalansen. Tidsskr Nor Legeforen 20o9; 129: 858-62.

4. Åsberg A., Hveem K, Thorstensen K et al. Screening for hemochhromatosis: high prevalence and low morbidity in an unselected population of 65238 persons. Scand J Gastroenterol 2001; 36: 1108-15.

5. Mouland G, Bratland B, Homnes M-B et al. Forhøyet serum-ferritinnivå og hemokromatose i allmennpraksis. Tidsskr Nor Lægeforen 2005; 125: $20-2$.

6. Hagve T-A, Åsberg A, Ulvik R et al. Hemokromatose - fra underdiagnostisert kuriositet til folkesykdom. Tidsskr Nor Legeforen 2009; 129: 863-6.

Publisert: 19. november 2009. Tidsskr Nor Legeforen. DOI: 10.4045/tidsskr.09.1076

(C) Tidsskrift for Den norske legeforening 2023. Lastet ned fra tidsskriftet.no 26. april 2023. 